\title{
Monthly Progress Report for November 1975 for the HTGR Safety Studies for the Division of Technical Review U.S. Nuclear Regulatory Commission
}

\author{
J.P. Sanders, Manager
}

\section{OAK RIDGE NATIONAL LABORATORY}




\section{DISCLAIMER}

This report was prepared as an account of work sponsored by an agency of the United States Government. Neither the United States Government nor any agency Thereof, nor any of their employees, makes any warranty, express or implied, or assumes any legal liability or responsibility for the accuracy, completeness, or usefulness of any information, apparatus, product, or process disclosed, or represents that its use would not infringe privately owned rights. Reference herein to any specific commercial product, process, or service by trade name, trademark, manufacturer, or otherwise does not necessarily constitute or imply its endorsement, recommendation, or favoring by the United States Government or any agency thereof. The views and opinions of authors expressed herein do not necessarily state or reflect those of the United States Government or any agency thereof. 


\section{DISCLAIMER}

Portions of this document may be illegible in electronic image products. Images are produced from the best available original document. 
Printed in the United States of America. Available from National Technical Information Service

U.S. Department of Commerce

5285 Port Royal Road, Springfield, Virginia 22161

Price: Printed Copy $\$ 4.50$; Microfiche $\$ 2.25$

This report was prepared as an account of work sponsored by the United States Government. Neither the United States nor the Energy Research and Development Administration, nor any of their employees, nor any of their contractors, subcontractors, or their employees, makes any warranty, express or implied, or assumes any legal liability or responsibility for the accuracy, completeness or usefulness of any information, apparatus, product or process disclosed, or represents that its use would not infringe privately owned rights. 
Contract No. W-7405-eng-26

\author{
MONTHLY PROGRESS REPORT FOR NOVEMBER 1975 \\ for the \\ HTGR SAFETY STUDIES FOR THE \\ DIVISION OF TECHNICAL REVIEW \\ U.S. NUCLEAR REGULATORY COMMISSION
}

J. P. Sanders, Manager

DECEMBER 1975

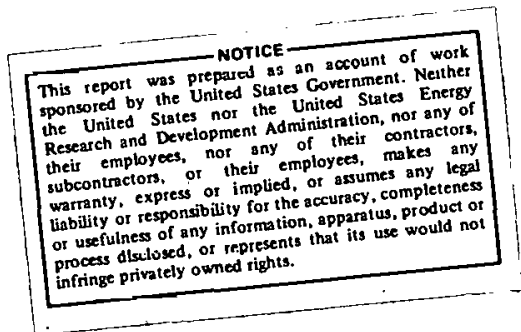

(This work was performed for the U.S. Nuclear Regulatory

Commission under interagency agreement ERDA No. 40-494-75)

NOTICE: Thio document contains information of a preliminary nature and was prepared primarily for internal use at the Oak Ridge National Laboratory. It is subject to revision or correction and therefore does not represent a final report.

OAK RIDGE NATIONAL LABORATORY

Oak Ridge, Témessee 37830

operated by

UNION CARBIDE CORPORATION

for the

U.S. ENERGY RESEARCH AND DEVELOPMENT ADMINISTRATION 


\section{THIS PAGE}

\section{WAS INTENTIONALLY LEFT BLANK}


CONTENTS

I. INTRODUCTION $\ldots \ldots \ldots \ldots \ldots \ldots \ldots \ldots \ldots \ldots \ldots \ldots \ldots \ldots \ldots \ldots$

II. THERMAL CALCULATIONS FOR THE FORT ST, VRAIN HTGR $\ldots \ldots \ldots$. 2

III. HEXERE I CODE DEVELOPMENT . ................... 2

IV. AIR INGRESS TO THE PCRV FOLLOWING DEPRESSURIZATION $\ldots . .3$

V. CONVECTIVE HEAT TRANSPORT MODELING IN THE FLODIS CODE $\ldots$

VI. USE OF THE COMMON DIGITAL MODEL OF ANC FOR HTGR

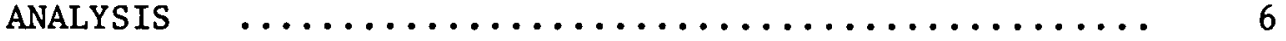


MONTHLY PROGRESS REPORT FOR NOVEMBER 1975

HTGR SAFETY STUDIES FOR THE

DIVISION OF TECHNICAL REVIEW

U.S. NUCLEAR REGULATORY COMMISSION

\section{INTRODUCTION (J. P. Sanders)}

This is the fifth in a series of monthly reports describing work performed for the Division of Technical Review, USNRC, concerning the analysis of the transient response of HTGR systems under abnormal conditions. As in the previous report, the work described is for the period from October 15 through November 15 to provide for a timely publication schedule.

A draft of the report (ORNL-TM-5140) describing the results of the computations at ORNL for the Fort St. Vrain design base depressurization accident (DBDA) followed by operation with two Pelton wheel drives at $7000 \mathrm{rpm}$ has been completed. The draft report was transmitted to the Gas Cooled Reactors Branch of the Division of Reactor Licensing and to the Division of Technical Review for their comments and immediate information. The final report is being prepared, and it should be in final reproduction by the end of November.

A draft report (ORNL-TM-5144) was completed and transmitted to the Division of Technical Review for comment. This report describes a computer code that had been written to predict the air ingress rate from the containment volume into the primary system of a large HTGR following a depressurization accident. The final report is in the process of reproduction. This computer program will be incorporated as a subroutine in the overall operational analysis program for the CACS.

A modification of the FLODIS calculation has been incorporated in the HEXEREI code as a subroutine to determine the flow distribution at the low coolant flows provided by the auxiliary systems. HEXEREI is a multi-channel, lumped-node, coupled conduction-convection code to evaluate the thermal conditions in the core. Trial runs for the Fort St. Vrain DBDA have been executed with this combination for short periods into the transient. After all aspects. of the calculation have been evaluated, the complete transient will be executed. 
This combination has also been coupled with the ACHERONS package, which is a CACS performance code, and the combination has been executed as a total loop calculation.

The 189 No. B0004 describing these studies for the Divisinn of Technical Review has been modified to reflect the level of funding in the program letter from R. E. Heineman to R. J. Hart, dated August 5, 1975. The work to be accomplished has been modified to reflect the task areas outlined in the program letter as consistent with the funding level. This revision has reflected recent information obtained from personnel in the Division of Technical Review.

II. THERMAL CALCULATIONS FOR THE FORT ST. VRAIN HTGR (J. P. Sanders) A report (ORNL-TM-5140) has been prepared to present the results of the studies relative to the Fort St. Vrain DBDA. This report is in the process of reproduction. The abstract for the report is as follows:

Independent computations have been performed at ORNL to determine the thermal and hydraulic response of the primary system of the Fort St. Vrain reactor to a specified design basis depressurization accident (DBDA). For this accident it is stated that two of the four auxiliary drives on the circulators start operating at $7000 \mathrm{rpm}$ after a 5-min delay. Detailod tabulatinns describing this response were provided by the vendor, General Atomic Company (GAC). The calculations at ORNL supported the values given for primary system flow and pressure loss, and they confirmed the heat removal capacity of the flooded steam generators. The fuel and outlet helium temperatures calculated by ORNL generally reached higher values during the transient due to the fact that the ORNL calculations were performed using a single-channel calculation that could not include the effect of interregional heat conduction. An ORNL code that, is developmental, but which includes interregional conduction, agrees well with the GAC values. The results of these calculations are presented graphically.

III. HEXEREI CODE DEVELOPMENT (G. E. Giles, B. R. Becker, R. M. DeVault)

The HEXEREI code now consists of the basic core package (conductionconvection calculations with flow redistribution) and the ACHERONS package. Thus the code is capable of calculating the core thermal hydraulic performance and checking the performance of the CACS. The code is capable 
of using ACHERONS. to drive the core calculations but at present this has not been checked out. Calculation of specific test:cases has been completed and shows good agreement with other ORNL codes or analytical results. In addition, the Fort St. Vrain reactor was modeled on HEXEREI for a DBDA and compared well with the single axial node results of D. D. Paul for the steady state. Significant differences occur during the transient and are currently being investigated.

IV. AIR INGRESS TO THE PCRV FOLLOWING DEPRESSURIZATION (J. P. Sanders)

A short computer program has been written to determine the air ingress rate from the containment to the primary system of a large HTGR following a depressurization accident. 'This program will be incorporated as a subroutine in the CACS-loop performance code in the near future. This computer program has been independently documented in a report (ORNLTM-5144) that is currently being reproduced and distributed. The abstract for this report is as follows:

The computer program INGRES was written to calculate the rate of air ingress into the prestressed concrete reactor vessel after a design-basis depressurization accident in a . high-temperature gas-cooled reactor. The model includes the free convection loop that can occur in a cold-leg break, the expansion and contraction air exchange mechanisms, and the conversion of oxygen to carbon monoxide. Results are presented for the 2000-MW( $t$ ) Summit Power Station and the 3000MW( $t$ ) Fulton Generating Station and are compared to computational results provided by the General Atomic Company. The results agree reasonably well even though some differences exist In llie lwo mudels.

V. CONVECTIVE HEAT TRANSPORT MODELING IN THE FLODIS CODE (D. D. Pau1)

There have been some questions concerning the validity of techniques currently used to describe convective heat transport in energy balance equations. Commonly, a driving potential for heat transfer is based on the difference between the solid node temperature and the arithmetic average temperature of the inlet and outlet coolant temperature for the length of coolant channel associated with the node: It is very difficult to ascertain the accuracy of such an arbitrary procedure; consequently, 
alternative methods were investigated. Within the framework of equations derived for use in the FLODIS code, an exact solution of the convective heat transport term has been obtained.

The coolant energy balance equation may be integrated directly if the assumptions are made that the capacitance term is negligibly small compared with the other terms and that the solid node temperature is constant over the length of the node. The resulting solution of the differential equation is

$$
\dot{\theta}(z)=T_{w}-\left(T_{w}-\theta_{i n}\right) e^{-\alpha z},
$$

where

$$
\begin{aligned}
\theta & =\text { the bulk coolant temperature, } \\
T_{w} & =\text { the corresponding solid node wall temperature, } \\
z & =\text { the axial node length, } \\
\alpha & =\text { the decay constant defined by } \\
\alpha & =\frac{H P}{\mathrm{WC}_{\mathrm{P}}}
\end{aligned}
$$

where

$$
\begin{aligned}
& H=\text { the local convective heat transfer coefficient, } \\
& P=\text { the wetted perimeter of the channel, } \\
& W=\text { the coolant mass flow rate in the channel, } \\
& C_{P}=\text { the heat capacity of the coolant. }
\end{aligned}
$$

Figure 1. shows two temperature profiles over a single node depending on the node spacing $\mathrm{L}$. The solid temperature is constant over the node, and it may be interpreted as the volume averaged temperature of the node. The coolant temperature approaches the solid node temperature exponentially according to Eq. (1).

For the differential segment $d z$, the differential quantity of heat transported by convection is

$$
d Q=H P\left[T_{w}-\Theta(z)\right] d z
$$

Equation (1) may be substituted into Eq. (3), and the differential quantities summed by integration to give 


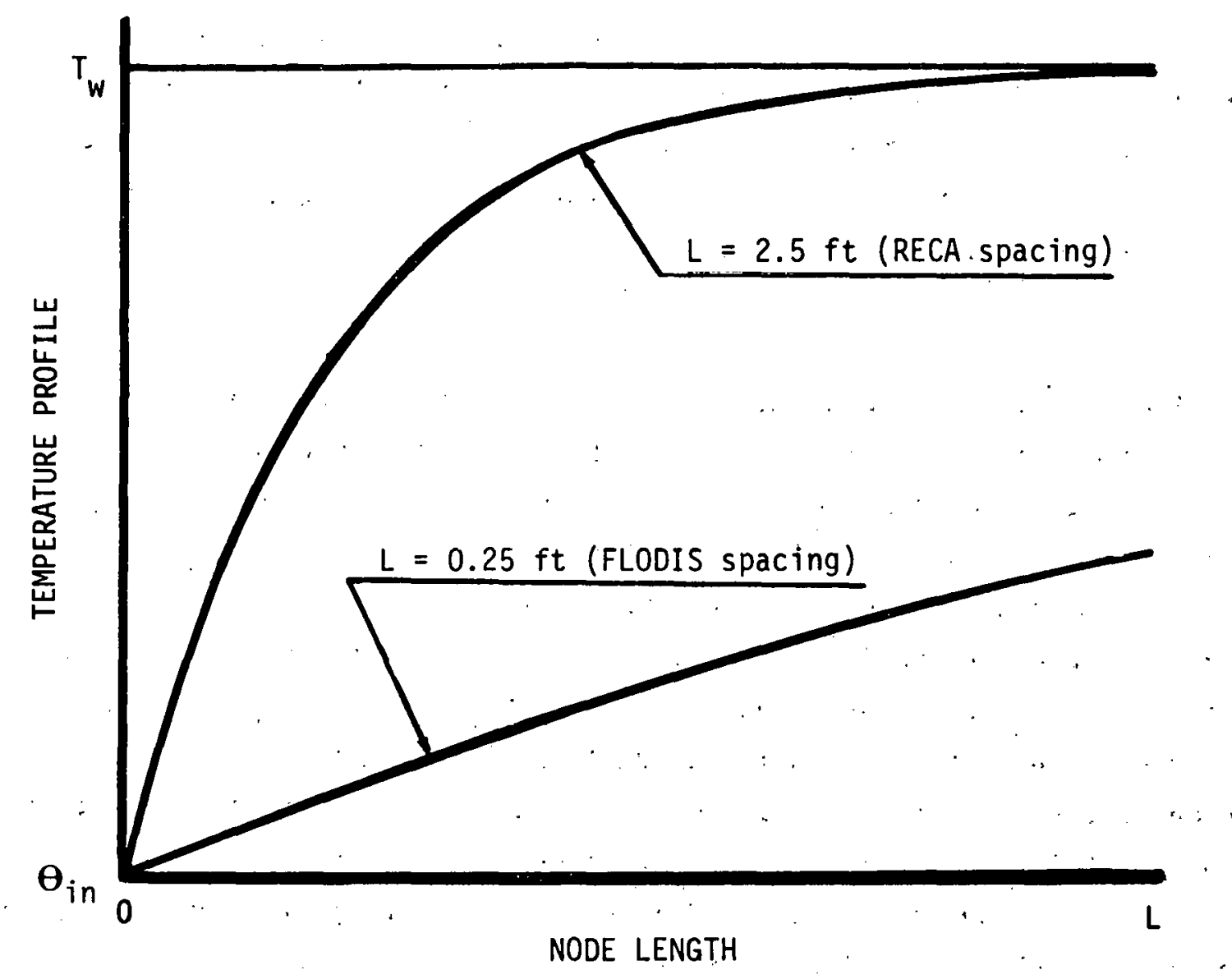

Fig. 1. Typical wall and coolant temperature profiles for different node spacings. Plots are based on $\alpha=2.0 \mathrm{ft}^{-1}$, which is typical for the Fort St. Vrain reactor following a DBDA.

$$
Q=H P L\left[\left(T_{w}-\theta_{i n}\right)\left(\frac{1-e^{-\alpha L}}{\alpha L}\right)\right] \text {. }
$$

The expression in the brackets can be interpreted as the average temperature difference between the wall and coolant over a single node. For convenience, the averaging factor can be defined as

$$
\zeta=\left(\frac{1-e^{-\alpha L}}{\alpha L}\right)
$$

and the convective heat transport term becomes

$$
Q=\operatorname{HrL} \zeta\left(T_{w}-\dot{\theta}_{1 \mathrm{n}}\right)
$$


This expression is now exact in that it correctly accounts for the variation of the temperature difference between the wall and the coolant.

Examination of Fig. 1 indicates that the arithmetic average technique will produce errors for "large" node spacings. By large, it is meant node spacings such that

$$
\alpha \mathrm{L} \gg 0.1 \text {. }
$$

Typical values of $\alpha \mathrm{L}$ used in the FLODIS code are on the order of 0.5 . For the arithmetic average technique to be valid, the number of axial nodes would have to be increased by a factor of 5 ; this would bring the total number of nodes to 500 per refueling region. This is impractical from a computational standpoint, and, in fact, unnecessary if the averaging factor derived in Eq. (5) is used. However, the foregoing developments raise some serious questions about the validity of gross lumping methods such as those used in the RECA program. In this respect, the planned review by the Division of Technical Review of the topical report on the RECA code should prove interesting.

A report describing the FLODIS code is presently being prepared, and a draft should be available for review. by the end of December. Included in the report will be an analysis of the Fort St. Vrain design basis depressurization accident.

VI. USE OF THE COMMON DIGITAL MODEL OF ANC FOR HTGR ANALYSIS (K. W. Childs)

In response to a letter, dated August 5, 1975, from L. H. Sullivan of the Division of Technical Review, the CDM (Common Digital Model) computer program developed by the Aerojet Nuclear Company has been reviewed. The purpose of this review was to determine the applicability of this program with its modular structure to HTGR transient analysis modeling. The conclusion of this review is that it would not be practical to use the CDM directly because of the extensive modifications which would be required. The major difficulties are outlined below:

(1) The CDM was written to analyze the NERVA rocket engine. Because of the dissimilarity of the components in the NERVA system as compared to the HTGR, it would be necessary to either write new predictor and corrector 
models or extensively modify existing ones for all components of the HTGR system.

(2) The NERVA rocket engine is a once-through system, whereas the HTGR is a closed system in which the coolant is recirculated. The CDM would require additional programming added to represent this difference.

(3) HTGR system control restraints would have to be included in the CDM.

Considering the extent of the modifications necessary to use the CDM, it appears that a greater effort would be required to modify it than would be required to develop an independent program specifically for the HTGR analysis.

The predictor-corrector method of solution used in the Common Digital Model appears to have merit in reducing computing time when modeling complicated systems. Because of the potential to reduce computing time, this method should be considered in the development of the HTGR analysis methods. 
THIS PAGE

WAS INTENTIONALLY

LEFT BLANK 
ORNL-TM- 5205

\section{Internal Distribution}

1. S. J. Ball

2. B. R. Becker

3. J. P. Callahan

4. T. E. Cole

5. J. H. Coobs

6. W. B. Cottrell

7. F. L. Culler

8. R. M. DeVault

9. G. G. Fee

10. Uri Gat

11. G. E. Giles, Jr.

12. M. J. Goglia

13. H. W. Hoffman

14-15. P. R. Kasten

16. A. L. Lotts

17. R. E. MacPherson

18. A. P. Malinauskas

19. W. J. McCarthy, Jr.
20. K. J. Notz

21. D. D. Paul

22. H. Postma

23. M. W. Rosenthal

24-27. J. P. Sanders

28. J. E. Sease

29. Dunlap Scott

30. I. Spiewak

31. J. J. Taylor

32. D. B. Trauger

33. W. D. Turner

34. G. D. Whitman

35. W. J. Wilcox

36. ORNL Patent office

37-38. Central Research Library

39. Document Reference Section

40-41. Laboratory Records Department

42. Laboratory Records (RC)

\section{External Distribution}

43. Assistant Director, Gas-Cooled Reactor Projects, RRD-G, ERDA, Wash.

44. Assistant Director, Reactor Safety, RRD-R, ERDA, Wash.'

45. Chief, Gas-Cooled Reactor Systems Branch, RRD-GS, ERDA, Wash.

46. Chief, Fuels Technology Branch, RRD-GF, ERDA, Wash.

47. Chief, Gas Reactor Safety Branch, RRD-RG, ERDA, Wash.

48-50. Office of Reactor Research Coordination, ERDA, Wash.

51. Director, Reactor Division, ERDA, ORO

52. Director, Research and Technical Support Division, ERDA, ORO

53-79. Technical Information Center, ERDA, ORO

80-129. Assistant Director, Reactor Safety, NRC/NRR/DTR, Wash.

130. Director, Office of Nuclear Regulatory Research, NRC, Wash.

131. Assistant Director, Research Coordination, NRC/RES, Wash.

132. Assistant Director, Advanced Reactor Safety Research, NRC/RES, Wash.

133. Chief, Experimental Gas-Cooled Reactor Safety Research Branch, NRC/RES, Wash.

134-136. W. Kirk, Los Alamos Scientific Laboratory, P. 0. Box 1663, Los Alamos, N. Mex. 37544

137-139. D. Schweitzer, Brookhaven National Laboratory, Upton, L. I., N. Y. 11973 